Tropical Journal of Pharmaceutical Research April 2020; 19 (4): 859-864

ISSN: $1596-5996$ (print); 1596-9827 (electronic)

(C) Pharmacotherapy Group, Faculty of Pharmacy, University of Benin, Benin City, 300001 Nigeria

\title{
A sensitive and rapid HPLC-DAD method for the determination of 3-hydroxy-1,2-dimethyl-4-pyridone and its distribution in rats
}

\author{
Mengdi Chen, Ping Liu*, Xuejiao Zhang, Shuling Li, Qiongyao Zhang \\ Department of Physical and Chemical Inspection, School of Public Health, Shandong University, Jinan, Shandong, China \\ *For correspondence: Email: 1149497831@qq.com, liupingp@sdu.edu.cn; Tel: +86 053188382554 \\ Sent for review: 12 August 2019 \\ Revised accepted: 29 January 2020
}

\begin{abstract}
Purpose: To establish a sensitive and rapid method for the determination of the tissue distribution of 3hydroxy-1,2-dimethyl-4-pyridone (L1) in vivo, and its plasma protein binding capacity.

Methods: This study optimized a reverse-phase HPLC method for specific and sensitive determination of $L 1$ as well as its plasma and tissue distributions. The optimized method was used to determine the plasma protein-binding capacity of $L 1$ in Wistar rats.

Results: A rapid, sensitive and simple HPLC-DAD method was established for studying the plasma and tissue distribution of L1. Following $\mathrm{TI}$ administration, its liver concentrations peaked at $60 \mathrm{~min}$ and 360min, followed 360 min later with peak level in the kidney (second highest). The L1 concentration was significantly lower after $360 \mathrm{~min}$ than after $60 \mathrm{~min}$, and values of its mean binding to plasma proteins was $5.2 \%$ at different $L 1$ concentrations.

Conclusion: These results indicate that $L 1$ is a drug with rapid-absorption and rapid-elimination thath is distributed widely in vivo in rats. Moreover, the drug has a weak plasma protein-binding capacity.
\end{abstract}

Keywords: 3-Hydroxy-1,2-dimethyl-4-pyridone, Distribution, Alzheimer's disease, Therapy

\begin{abstract}
This is an Open Access article that uses a fund-ing model which does not charge readers or their institutions for access and distributed under the terms of the Creative Commons Attribution License (http://creativecommons.org/licenses/by/4.0) and the Budapest Open Access Initiative (http://www.budapestopenaccessinitiative.org/read), which permit unrestricted use, distribution, and reproduction in any medium, provided the original work is properly credited.
\end{abstract}

Tropical Journal of Pharmaceutical Research is indexed by Science Citation Index (SciSearch), Scopus, International Pharmaceutical Abstract, Chemical Abstracts, Embase, Index Copernicus, EBSCO, African Index Medicus, JournalSeek, Journal Citation Reports/Science Edition, Directory of Open Access Journals (DOAJ), African Journal Online, Bioline International, Open-J-Gate and Pharmacy Abstracts

\section{INTRODUCTION}

Aluminum is associated with chronic toxicity, with the nervous system as its main target [1]. Studies have shown that aluminum is a possible risk factor for some neurodegenerative illnesses, including Alzheimer's disease [2, 3]. 3-Hydroxy1,2-dimethyl-4-pyridone (L1) is an orally-active iron chelator which is used for the treatment of iron overload [4]. In addition, L1 has aluminumchelating capacity [5]. Thus, L1 may be beneficial in the prevention and treatment of neurodegenerative illnesses through enhancement of excretion of aluminum. However, high-dose L1 may lead to toxic effects in vivo through chelation of essential elements. With growing significance of L1, a number of analytical methods have been established for determination of its distribution in vivo, but these methods lack satisfactory repeatability and convenience of use [6-8].

In the present study, a reverse-phase HPLC method for the specific and sensitive detection of 
L1 was optimized and applied for the determination of plasma and tissue distributions of $L 1$ in rats, as well as $L 1$ plasma proteinbinding capacity of $\mathrm{L} 1$.

\section{EXPERIMENTAL}

\section{Materials and reagents}

3-Hydroxy-1,2-dimethyl-4-pyridone was obtained from Aladdin Industrial Corporation; HPLC-grade methanol and acetonitrile were products of Yuwang Industrial Corporation. Sodium heptanesulfonate, $\mathrm{NaH}_{2} \mathrm{PO}_{3}$ and other reagents were $A R$ grade. Deionized water was obtained from a Milli-Q apparatus (Millipore, Bedford, MA, USA).

\section{Animal sub-grouping and treatments}

Fifty male Wistar rats (mean weight $=325 \pm 20$ g) were obtained from the Laboratory Animal Center, Shandong University. The experimental procedures used in this study were approved by the Institutional Animal Ethics Committee of the College of Public Health, Shandong University (approval number: 20120601). Forty rats were randomly divided into 4 groups (10 rats per group) for plasma and tissue distribution studies. The blank group was orally administrated $1 \mathrm{~mL}$ of physiological saline, while rats in the other groups were treated with $L 1$ at a dose of 70 $\mathrm{mg} / \mathrm{kg}$. The rats were sacrificed via decapitation after 10, 60 or $360 \mathrm{~min}$.

Blood, heart, kidney, stomach, liver, spleen, lung, testis, muscle, brain and small intestine were taken out rapidly. The blood samples were anticoagulated with heparin, and the tissues were washed with physiological saline, blotted with filter paper, and made into $20 \%$ homogenates. The other 10 rats were decapitated directly. The anticoagulated blood samples were used for determination of plasma protein binding capacity of L1. The samples were centrifuged at $604 \times \mathrm{g}$ for $10 \mathrm{~min}$, and the resultant plasma samples were kept at $4{ }^{\circ} \mathrm{C}$. All tissue homogenates were preserved at $-20{ }^{\circ} \mathrm{C}$ prior to use.

\section{HPLC conditions}

This study was conducted using HPLC coupled to a diode array detector with a $\mathrm{C}_{18}$ column (5 $\mu \mathrm{m}, 250 \mathrm{~mm} \times 4.6 \mathrm{~mm}$, Diamonsil) at $25^{\circ} \mathrm{C}$. The mobile phase consisted of acetonitrile-phosphate buffer $(\mathrm{pH}=3)$ at volume ratios of 8:92 for plasma, and 1:9 for tissue homogenates and extra-dialysate. A flow rate of $1.0 \mathrm{~mL} / \mathrm{min}$ was used.

\section{Plasma and tissue distribution analyses}

Each sample was diluted with an equal amount of acetonitrile, and centrifuged at $6708 \times \mathrm{g}$ for 5 min. Then, $100 \mu \mathrm{L}$ supernatant was taken and diluted with $400 \mu \mathrm{L}$ mobile phase. An aliquot (20 $\mu \mathrm{L}$ ) of the supernatant was injected into the HPLC system after filtration with a $0.45 \mu \mathrm{m}$ filter.

\section{Plasma protein binding assay}

\section{Balance time analysis}

Blank plasma (1 mL) was put into a dialysis bag, and placed in $10 \mathrm{~mL}$ of different concentrations of $\mathrm{L} 1$ at $37^{\circ} \mathrm{C}$. The concentrations of drug inside $\left(c_{1}\right)$ and outside $\left(c_{2}\right)$ were determined. The plasma protein binding of L1 (f) was calculated using equation:

$F=\left(c_{1}-c_{2}\right) / c_{1} \times 100$

\section{Absorption of dialysis bag}

In this measurement, $1 \mathrm{~mL}\left(\mathrm{~V}_{1}\right)$ of phosphate buffer $(\mathrm{pH}=7.4)$ was put into a dialysis bag, and placed in $10 \mathrm{~mL}\left(\mathrm{~V}_{2}\right)$ of different concentrations (c3) of $\mathrm{L} 1$ at $37^{\circ} \mathrm{C}$ for $4 \mathrm{~h}$. The concentrations of the extra-dialysate $\left(c_{4}\right)$ were determined. The absorption was calculated as shown in Equation 2:

$\mathrm{X}=\left\{\left[\mathrm{c}_{3} \times \mathrm{V}_{2}-\mathrm{c}_{4} \times\left(\mathrm{V}_{1}+\mathrm{V}_{2}\right)\right] /\left(\mathrm{c}_{3} \times \mathrm{V}_{2}\right)\right\} \times 100 \ldots \ldots(2)$

\section{Plasma protein binding of L1 in samples}

The intra-dialysate and extra-dialysate samples were reconstituted with $100 \mu \mathrm{L}$ acetonitrile, and centrifuged at $6708 \times \mathrm{g}$ for $5 \mathrm{~min}$. Then, $100 \mu \mathrm{L}$ supernatant was mixed with $400 \mu \mathrm{L}$ mobile phase, and an aliquot $(20 \mu \mathrm{L})$ of the supernatant was injected into the HPLC system after filtration through a $0.45 \mu \mathrm{m}$ filter.

\section{Statistical analysis}

Data are expressed as mean \pm standard deviation (SD). Statistical analysis was done using Student's $t$-tests. Statistical significance of difference was fixed at $p<0.05$.

\section{RESULTS}

\section{Optimization of HPLC-DAD}

\section{Detection wavelength}

A standard solution of L1 was scanned between $190 \mathrm{~nm}$ and $400 \mathrm{~nm}$ in an Ultraviolet-Visible Spectrophotometer. The scanning spectrum of 
L1 is shown in Figure 1. There were strong UV absorptions at wavelengths of 202, 216 and 278 $\mathrm{nm}$.

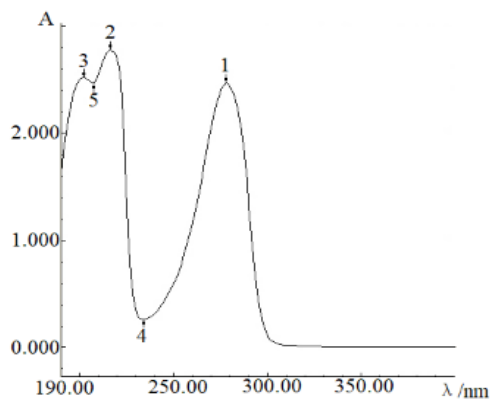

Figure 1: UV spectra of $L 1$

\section{Method validation}

The chromatograms of the blank plasma, tissue homogenates and extra-dialysate were obtained using the optimized HPLC method (Figure 2). Blank plasma, tissue homogenates and extradialysate with L1 standard were analyzed (Figure 3). The chromatograms for plasma, tissue homogenates and extra-dialysate of samples are shown in Figure 4. It is apparent that the endogenous substances in plasma, tissue homogenates and extra-dialysate did not interfere with the peak of L1. Thus, the optimized method is specific for the measurement of L1.
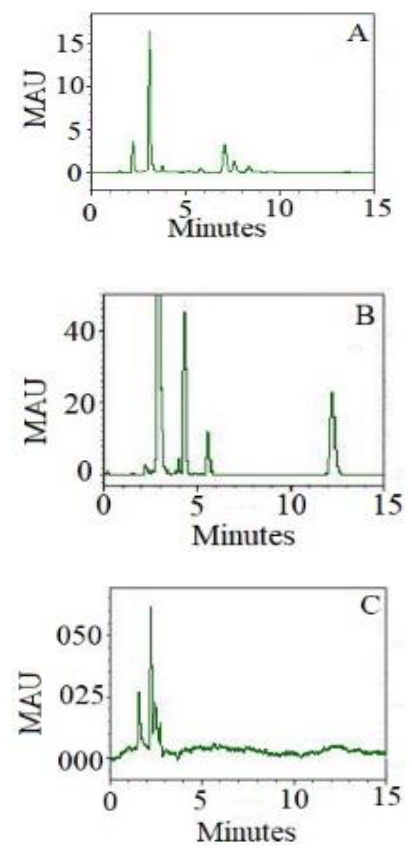

Figure 2: HPLC chromatograms of blank groups. A: plasma blank; B: tissue homogenate blank; C: extradialysate blank
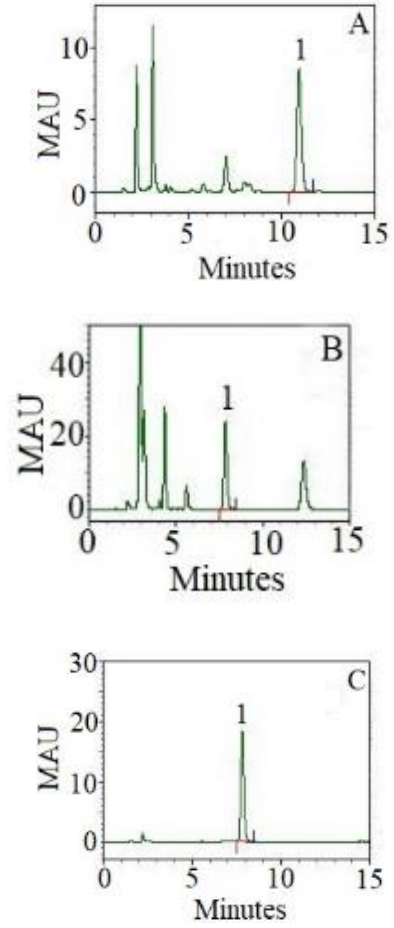

Figure 3: HPLC chromatograms of L1 in the blank plasma, tissue homogenate blank and extra-dialysate blank. A: plasma blank with L1; B: tissue homogenate blank with L1; C: extra-dialysate blank with L1
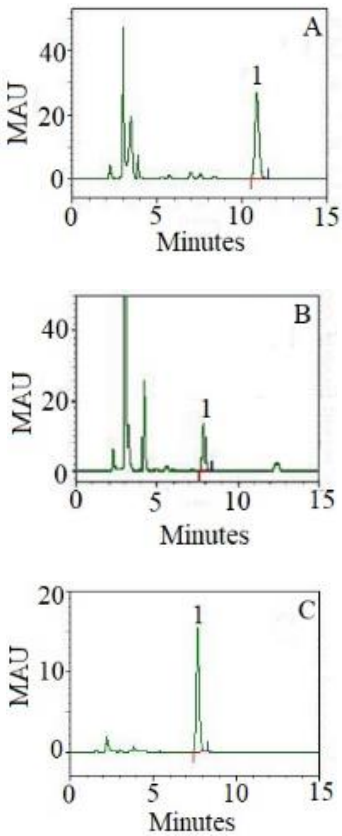

Figure 4: HPLC chromatograms of L1 in rat plasma, tissues and dialysate. A: plasma sample; $B$ : tissue homogenate; C: extra-dialysate

\section{Standard curve}

When L1 concentration was in the range of 1-100 $\mathrm{mg} / \mathrm{L}$ in plasma or $0.1-100 \mathrm{mg} / \mathrm{L}$ in tissue

Trop J Pharm Res, April 2020; 19(4):861 
homogenate and extra-dialysate, peak area and concentration showed good linear relationship, with the regression equations: $y=29952.49 x-$ $4137(r=0.99974)$, and $y=31143.78 x-2663(r$ $=0.99983)$, respectively. The limits of detection were 6.1 and $5.9 \mu \mathrm{g} / \mathrm{L}$, respectively.

\section{Recovery and precision}

Serial concentrations of standard solution of L1 (5, 40 and $80 \mathrm{mg} / \mathrm{L}$ were added to the plasma blank. The concentration of L1 was determined 5 times repeatedly for each solution. The tissue homogenate blank and extra-dialysate blank were treated in the same way. In plasma, the recoveries were in the range of $99.04-100.34 \%$ at low, middle and high concentrations, while in tissue homogenates and extra-dialysate, the recoveries were in the range of 95.93 - 105.22 $\%$. The coefficients of variation at all concentrations were less than $4.1 \%$.

\section{Distribution of $L 1$ in the rats}

As shown in Figure 5, 10 min after intragastric administration of $\mathrm{L} 1$, it was detected in plasma and all tissues, with the highest level in the stomach. After $60 \mathrm{~min}$, the liver content of L1 $(247.3 \mathrm{mg} / \mathrm{kg}$ ) was significantly higher than that in other tissues. After $360 \mathrm{~min}$, liver L1 content $(57.3 \mathrm{mg} / \mathrm{kg}$ ) was significantly higher than that in other tissues, followed by the kidney $(12.1 \mathrm{mg} / \mathrm{kg})$. The plasma and tissue concentrations of $\mathrm{L} 1$ at 360 min were significantly lower than those at 60 .

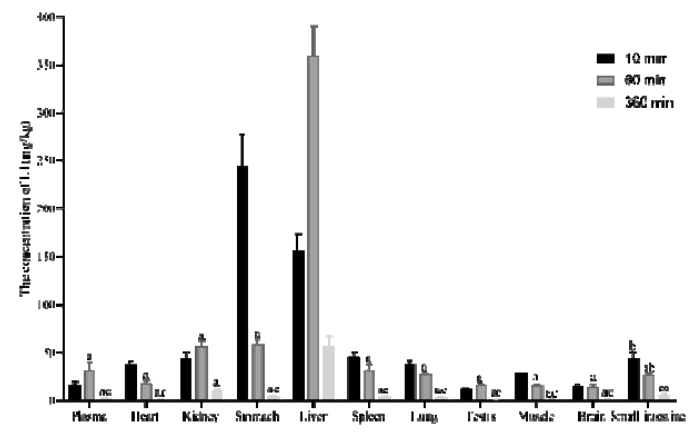

Figure 5: L1 distribution in tissues at a dose of 70 $\mathrm{mg} / \mathrm{kg}$ at $10 \mathrm{~min}, 1 \mathrm{~h}$ and $6 \mathrm{~h}$. a: $p<0.001$, compared with the liver concentration of L1 in the same group, ${ }^{b} p$ $<0.001$, compared with the stomach concentration of L1 in the same group; ${ }^{c} p<0.001$, compared with that of kidney in the same group

\section{Plasma protein binding}

It took at least $2 \mathrm{~h}$ to reach dialysis equilibrium for $\mathrm{L} 1$ at $37^{\circ} \mathrm{C}$ under the experimental conditions (Figure 6). After dialysis equilibrium, the average percentage of $\mathrm{L} 1$ bound to plasma proteins ranged from 4.1 to $5.2 \%$. There were no significant differences in the capacities of different concentrations of L1 to bind to plasma proteins $(p>0.05)$.

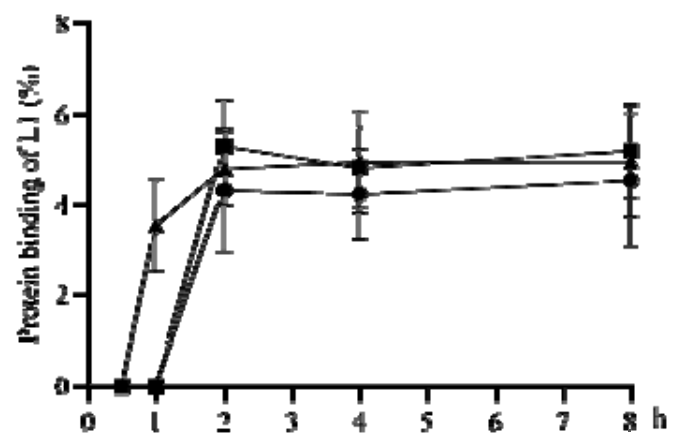

Figure 6: Protein binding of various $L 1$ concentrations $(n=5$. Key: $\bullet=15 \mathrm{mg} / \mathrm{L}, \boldsymbol{\square}=30 \mathrm{mg} / \mathrm{L}, \boldsymbol{\Delta}==60$ $\mathrm{mg} / \mathrm{L}$

The mean adsorption of $L 1$ to the dialysis bag was below $4.6 \%$ (Figure 7 ).

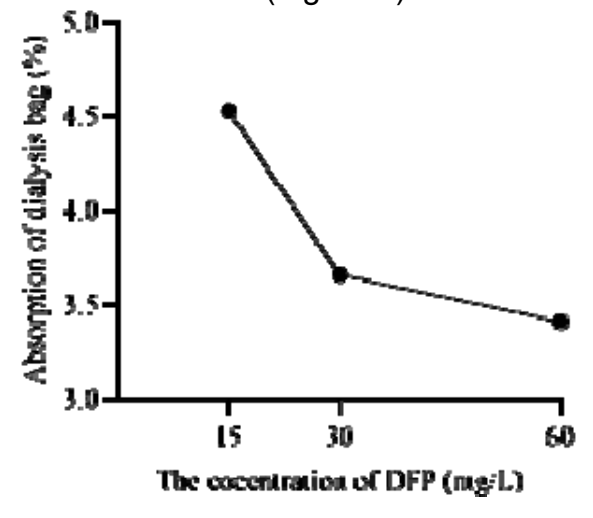

Figure 7: Adsorption of $L 1$ to dialysis bag

\section{DISCUSSION}

As shown in the results, L1 had strong UV absorption at wavelengths of $202 \mathrm{~nm}, 216 \mathrm{~nm}$ and $278 \mathrm{~nm}$. Since the mobile phase and the impurity in plasma interfere with the detection of L1 at short wavelengths, $278 \mathrm{~nm}$ was chosen as the detection wavelength in order to get better sensitivity and accuracy. To improve the peak symmetry and resolution of L1 from impurities, the chromatographic behaviors of different mobile phases i.e. trifluoroacetic acid-acetonitrile [6], trifluoroacetic acid-methanol, PBSacetonitrile [9], and PBS-methanol [10] were investigated. Furthermore, to eliminate tailing of peak, sodium heptanesulfonate was added. After many trials, a mobile phase containing acetonitrile-PBS $\left(0.05 \mathrm{~mol} / \mathrm{L} \mathrm{NaH} \mathrm{PO}_{3}, 5 \mathrm{mmol} / \mathrm{L}\right.$ 
sodium heptanesulfonate and $2 \mathrm{mmol} / \mathrm{L}$ EDTA, $\mathrm{pH}=3(8: 92$ or $1: 9, \mathrm{v} / \mathrm{v})$ was set up. The results of validation and recovery and precision experiments showed that a rapid, sensitive, and simple method was successfully established for the determination of $L 1$ which is suitable for use in studying the distribution and plasma protein binding capacity of $\mathrm{L} 1$.

Ten minutes after administration, L1 was detected in plasma and all tissues, including brain and testis, which means that L1 could cross the blood-brain and the testicular barrier. 3Hydroxy-1,2-dimethyl-4-pyridone was used to clear the aluminum-overload in the brain, as suggested in a previous study [5]. Drug level in the stomach was highest at 10 min after dosing, which may due to the fact that gastric emptying time in rats exceeds $10 \mathrm{~min}$. In the first $60 \mathrm{~min}$, the stomach concentration of L1 was far higher than that in the small intestine. However, 60 min later, the stomach concentration of $L 1$ decreased rapidly, but $L 1$ level in the small intestine did not increase significantly, which indicated that L1 was rapidly absorbed mainly in the stomach. The content of $\mathrm{L} 1$ in liver was highest except in the first $10 \mathrm{~min}$, indicating that the liver may have a certain affinity for L1. It was previously reported that L1 goes mainly to the liver after administration, with only very small amount metabolized via glucopyranoside acidification [11]. The content of the drug was highest in the liver $360 \mathrm{~min}$ after administration, indicating that its elimination was slow. Thus, L1 might accumulate in the liver after administration. This needs further investigations.

Highly aerobic tissues such as liver, spleen, heart, lung and kidney had higher concentrations of $L 1$, while those with poor blood oxygen content had lower L1 concentrations. The wide distribution of $\mathrm{L} 1$ might be related to its small molecular weight (139.15), high lipo-solubility and easy passage through the cell membrane via passive diffusion. 3-Hydroxy-1,2-dimethyl-4pyridone is filtered and excreted mainly in the kidney $[12,13]$. Most L1 is reabsorbed into the blood in the tubular cells through passive diffusion [14], while the remaining L1 is excreted in the urine. In this study, at 360 min after its administration, the kidney L1 content was next to that of the liver, but was below $1 / 5^{\text {th }}$ of the corresponding concentration in liver. It is difficult for $L 1$ to accumulate in rats, as evidenced by its short elimination half-life and quick clearance [15].

3-Hydroxy-1,2-dimethyl-4-pyridone exists partly in the free form in plasma, while some are bound to plasma proteins. The binding of drugs to plasma proteins directly or indirectly influences their transportation and pharmacological effects [16]. Usually, there is a dynamic equilibrium between the bound and free forms of a drug. The plasma protein-binding capacities of drugs are measured using equilibrium dialysis method [17], ultrafiltration [18], gel electrophoresis and microdialysis [19]; ultracentrifugation, and spectroscopic methods. The equilibrium dialysis method is simple, economical and devoid of interference. Perchloric acid was used to detect protein leakage after dialysis. The adsorption of L1 to the dialysis bag was minimal, indicating that it had no significant influence on the results. Plasma protein binding was obtained from the calculation of drug concentrations inside and outside the dialysis bag. There were no significant differences in percentage plasma protein binding among the low, middle and high concentrations of L1. Thus, the plasma protein binding of L1 was not concentration-dependent. Combination of drugs and plasma affects the action time of the drugs. The action time is shortened if the percentage plasma protein binding is low. In this study, L1 displayed pharmacodynamics mainly in the free form and so could be minimally competitive with other medicines.

\section{CONCLUSION}

A rapid, accurate, sensitive and reproducible HPLC-DAD method for the determination of 3hydroxy-1,2-dimethyl-4-pyridone has been established in this study. The results suggest that 3-hydroxy-1,2-dimethyl-4-pyridone is a rapidabsorption and rapid-elimination drug which is distributed widely in vivo in rats. Moreover, the drug has a low plasma protein-binding capacity.

\section{DECLARATIONS}

\section{Acknowledgement}

This work received financial support from Natural Science Foundation of Shandong Province, China (no. ZR2013CM043).

\section{Conflict of interest}

No conflict of interest is associated with this work.

\section{Contribution of authors}

We declare that this work was done by the authors named in this article and all liabilities pertaining to claims relating to the content of this article will be borne by the authors. The work 
was originally designed by Mengdi Chen, Ping Liu, Xuejiao Zhang, Shuling Li and Qiongyao Zhang, and the studies were carried out them. The first two authors wrote this manuscript. All authors read the manuscript before it was submitted for publication.

\section{Open Access}

This is an Open Access article that uses a funding model which does not charge readers or their institutions for access and distributed under the terms of the Creative Commons Attribution License (http://creativecommons.org/licenses/by/ 4.0) and the Budapest Open Access Initiative (http://www.budapestopenaccessinitiative.org/rea d), which permit unrestricted use, distribution, and reproduction in any medium, provided the original work is properly credited.

\section{REFERENCES}

1. Nayak P. Aluminum: impacts and disease. Environ Res 2002; 89(2): 101-115.

2. Campbell A, Bondy SC. Aluminum induced oxidative events and its relation to inflammation: a role for the metal in Alzheimer's disease. Cell Mol Biol 2000; 46(4): 721-730.

3. Jansson ET. Alzheimer disease is substantially preventable in the United States -- review of risk factors, therapy, and the prospects for an expert software system. Med hypotheses 2005; 64(5): 960-967.

4. Dean A, Ferlin MG, Cvijovic $M$, Djurdjevic $P$, Dotto $F$, Badocco $D$, Pastore $P$, Venzo $A$, Marco $V B D$. Evaluation of 1,2-dimethyl-3-hydroxy-4pyridinecarboxylic acid and of other 3-hydroxy-4pyridinecarboxylic acid derivatives for possible application in iron and aluminium chelation therapy. Polyhedron 2014; 67: 520-528.

5. Liu P, Yao YN, Wu SD, Dong HJ, Feng GC, Yuan XY. The efficacy of deferiprone on tissues aluminum removal and copper, zinc, manganese level in rabbits. $J$ Inorg Biochem 2005; 99(8): 1733-1737.

6. Huang XP, Spino $M$, Thiessen JJ. Transport kinetics of iron chelators and their chelates in Caco-2 cells. Pharm Res 2006; 23(2): 280-290.

7. Narang J, Malhotra $N$, Singh $G$, Pundir CS. Electrochemical impediometric detection of anti-HIV drug taking gold nanorods as a sensing interface. Biosens Bioelectron 2015; 66: 332-337.

8. Song TS, Hsieh YW, Peng CT, Liu CH, Chen TL, Hour MJ. Development of a fast LC-MS/MS assay for the determination of deferiprone in human plasma and application to pharmacokinetics. Biomed Chromatogr 2012; 26(12): 1575-1581.

9. Tu CY, Ho SP, Hung SW, Chen BR, Tsou LT, Wang WS. Development of a technique to detect the residue of oxolinic acid in the serum and muscle of Chinese mitten crab, Eriocheir sinensis. J Food Drug Anal 2006; 14(4): 391-397.

10. Zhang HM, Gao JL. Determination of the Content and Content Uniformity of Shunqi Huatan Tablets by HPLC. China Pharm 2012: 1-6.

11. Benoit-Biancamano MO, Connelly J, Villeneuve L, Caron $P$, Guillemette $C$. Deferiprone glucuronidation by human tissues and recombinant UDP glucuronosyltransferase 1A6: an in vitro investigation of genetic and splice variants. Drug Metab Dispos 2009; 37(37): 322-329.

12. Kontoghiorghe CN, Kolnagou A, Kontoghiorghes GJ. Potential clinical applications of chelating drugs in diseases targeting transferrin-bound iron and other metals. Expert Opin Investig Drugs 2013; 22(5): 591618.

13. Al-Khabori M, Bhandari S, Al-Rasadi K, Mevada S, AlDhuhli H, Al-Kemyani N, Daar S. Correlation of iron overload and glomerular filtration rate estimated by cystatin C in patients with N2-thalassemia major. Hemoglobin 2014; 38(5): 365-368.

14. Mccullough PA, Chinnaiyan KM. Hazards of contrastinduced acute kidney injury in elderly women. Womens Health 2009; 5(2): 123.

15. Abbas M, Nawaz R, Iqbal T, Alim M, Asi MR. Quantitative determination of deferiprone in human plasma by reverse phase high performance liquid chromatography and its application to pharmacokinetic study. Pak J Pharm Sci 2012; 25(2): 343-348.

16. Bugge JF. Influence of renal replacement therapy on pharmacokinetics in critically ill patients. Best Pract Res Clin Anaesthesiol 2004; 18(1): 175-187.

17. Zhang $H$, Wang $P$, Zhang $Y$, Liu H, Miao SY, Meng XL. Study on plasma protein binding rate of Rhubarb Free Anthraquinones by equilibrium dialysis method in rats' plasma. Pharmacology \& Clinics of Chinese Materia Medica 2012.

18. Xu F, Wu QN, Chen J, Gu W, Fang F, Zhang LQ, Zhao $B$. The binding mechanisms of plasma protein to active compounds in Alismaorientale rhizomes (Alismatis Rhizoma). BioorgMed Chem Lett 2014; 24(17): 40994105.

19. Kaur MJ, Prasad SR, Hartmut D. Determination of Atypical Nonlinear Plasma\&ndash; Protein-Binding Behavior of Tigecycline Using an In Vitro Microdialysis Technique. J Pharm Sci 2014; 103(3): 1013-1019. 